Journal of Engineering and Applied Sciences 14 (Special Issue 9): 10517-10521, 2019

ISSN: 1816-949X

(C) Medwell Journals, 2019

\title{
Selected Issues of Company Debt Resources Management in the Context of Tax Legislation
}

\author{
Martina Cerníkova and Sarka Hyblerova \\ Technical University of Liberec, Faculty of Economics, Liberec, Czech Republic
}

\begin{abstract}
For implementing partial activities, companies utilize a broad portfolio of financing resources. These resources can be analyzed from various angles. They are usually broken down into company's equity and debt sources. Although, the decision about resource utilization is influenced by many factors, the cost of capital is the most prominent aspect that enters this process. When examining the prices of company's equity and debt capital, it is necessary to take into account selected provisions of the tax laws which may significantly affect the cost of capital. The subject of the article is a research in the field of company debt resources. There are a number of circumstances that encourage companies to choose this method of financing. It is obvious that the motivation for the use of debt resources is different in terms of a company size. Our research was directed to explore this issue. There were investigated and evaluated the reasons for the use of debt resources of financing for the activities of variously sized companies in the Czech Republic. The research used primary data obtained by selective questionnaire survey. Using a comparative analysis, the data was processed, evaluated and interpreted. The output of the article confirms the categorization of the various factors influencing decisions about the use of debt resources with regard to the size of the surveyed companies.
\end{abstract}

Key words: Equity, debt capital, cost of capital, weighted average cost of capital, interest tax shield, thin capitalization test, company size, financial flexibility

\section{INTRODUCTION}

Corporate financing is one of the key areas of financial management. The optimal combination of financial resources contributes to the improvement of performance and maximizing of business value, it is also reflected in the process of structure formation of corporate assets.

The company uses a broad portfolio of resources for financing individual activities that can be classified from different perspectives. When deciding on the structure of financial resources, a wide range of non-financial factors plays an important role. These are for example, the stage of a company life cycle and the associated willingness of investors to invest their available funds into the company, a level and stability of profit, the structure of assets of the company and so on. Financing of the company is also largely influenced by the state policy in the area of taxation, customs, subsidies (or regulatory) and the situation on financial markets.

For a qualified decision on a capital structure or the structure of resources, a financial aspect represented by the amount of the costs of the various forms of capital is paramount. In the breakdown of resources on company's equity and debt resources, the cost represent the value of dividends or a profit share in case of company's own resources and interest on the loan or a bond in case of utilization of debt resources. Both, company's own and debt resources are used in varying extent and actually there are a number of reasons why the managers decide on the specific structure of these resources.

The aim of this study is to identify what factors influence company decisions on the use of debt resources or in other words what factors are the most significant for the company and its debt financing with regard to the company size. This issue was examined in the conditions of the Czech Republic.

\section{MATERIALS AND METHODS}

Theoretical solutions and problem solving methodology: The company utilizes a wide portfolio of funding resources which can be classified from various perspectives. The most widely used classification is based on the legal status of the provider of capital and divides capital or liabilities of the company into company's equity and debt capital. This categorization is the most common and is used mainly in theoretical studies attempting to define general optimal capital structure. In relation to evaluating the success of an entrepreneurial activity, the origin of the funding is also examined. The equity includes, among other things, registered capital or professional investors shares (venture capital, business angels), donations, grants, etc. that is the resources that were not generated by company's own business activities. From this perspective, the resources of financing can be divided into internal and external. 


\section{J. Eng. Applied Sci., 14 (Special Issue 9): 10517-10521, 2019}

The key question of a successful business then remains whether the choice of capital structure is appropriate (Barclay and Smith, 2005; Flandery and Rangan, 2006). Historically, many theories were postulated, initially based on cost criteria (Modigliani and Miller (1958) (Modigliani and Miller, 1958), later other elements that may have affected the capital structure appeared, e.g. taxes (Modigliani and Miller, 1963, Myers, 2001 and Auerbach, 2002) (Heins and Sprenkle, 1969; Miller, 1988; Durand, 1952). From the whole range of these theoretical postulates, it is clear that there is no simple algorithm to determine the optimal capital structure (Miller and Rock, 1985; Modigliani, 1988). Despite the diversity of business processes and activities, it can be observed that one of the most important factors for making decisions on the capital structure are the average cost of capital, the stability of corporate earnings, the amount of business risk, company asset structure, financial flexibility and demands of creditors (Modigliani and Miller, 1963, 1999).

Our research was directed to the area of debt resources. The involvement of company debt resources mainly happens through bank loans and using other debts that exist against external parties (suppliers, state, employees, etc). The issue of corporate bonds may be also considered. Utilization of debt resources has its own specifics and in deciding on the method of financing, company managers reflect many aspects. One of the important factors is the tax legislation of income tax which to a certain extent, allows using the, so called interest tax shield in financing activities from debt resources. The research defined the basic postulates that affect the use of debt resources by business entities. Using primary data, the obtained results were verified in the conditions of the Czech Republic. The methodologies applied cover the synthesis method, causal method, system and ratio analyses, inductions, deductions and comparisons.

Capital structure formation: Capital costs are the price the company must pay to the owners of the company resources, or a capital. The amount of these costs is crucial in terms of company management. A successful company must be able to produce a sufficient output not only for the long-term covering of cost of capital.

The cost of a company capital is collectively expressed through WACC indicator (Weighted Average Cost of Capital). This indicator also affects the interest rate for discounting future cash flows in investment decisions. If the average cost of capital is undervalued, it can lead to the adoption of investment projects which may ultimately reduce the market value of the company and conversely in the case of overvaluation, effective projects can be rejected. Also at assessing the company by income methods, capital costs play an important role
(Doukas et al., 2011). The interest rate derived from the average cost of a company capital may not only significantly affect the determination of the market value of the company as well as negotiating prices for its purchase or sale but can also play a key role in lawsuits for example when assessing the shares in the crowding out of minority shareholders, etc (Eun and Wang, 2015). The specific amount of the cost of individual types of capital depends on many factors (capital at maturity, the investor's risk and the smethod of payment of capital by a company etc.). Various types of a company capital can be classified according to their general cost.

Short-term debt is considered the cheapest source of a capital. With regard to short term maturity, the risk of a creditor is relatively low and the interest from a foreign capital is included in tax expenses.

Long-term debt is problematic in terms of costs. With a longer maturity, the risk of the lender (creditor) increases and thus, usually interest expense increases (which is also tax deductible).

Registered capital or equity (retained earnings) are the most problematic from this perspective. Equity is not amortized by repayments and a shareholder risk is substantially higher than the risk of the creditor. The cost of this capital in the form of dividends (shares) does not enter into the tax base (Kim, 1978).

Deciding on a suitable choice of the optimal company capital structure is a very complex process. The factor for the stability of the capital structure should not also be overlooked. Practical experience shows that usually it cannot be counted with constant cost of different types of capital and a fixed discount rate for the entire future period. Accounting and market value of capital structure evolves. This uncertainty makes the process of finding the optimal capital structure even more complicated.

Tax aspects of the use of debt resources: Tax legislation of income tax significantly affects the decision-making on the use of different sources of financing for business activities. Differing approaches to taxation of equity and debt capital offer space for a creative decision-making of managers on the construction of the capital structure, tax planning, so called tax management. A usual prerequisite about the capital structure of the company is the assumption that equity is more "expensive" than debt capital. This idea is based on the situation that returns on equity (profit sharing or dividends) do not represent cost in terms of tax legislation and do not enter into the tax base. Paying profit share or dividends is usually implemented from earnings after taxes and may be taxed to the recipient. This leads to double taxation which is unfavorable and undesirable for the company as well as the owner. In contrast, interest on loans and borrowings (including bond issues) come into the tax base of the company as a tax deductible expense and in the end, 
decrease its tax liability. This fact is reflected in the fact that companies widely use debt resources for the real business needs as well as for the possible tax planning. With the wide use of credits and loans, companies would reflect high interest on the debt in their tax base and thus, would greatly optimize their tax liability (Reznakova, 2012; Ho and Wang, 2015; Markova, 2015).

The above-mentioned aspects of taxation of income and capital costs are partly regulated by the European Union directives which have been gradually implemented into the national laws of the Member States. The effects of double taxation of dividend payments and profit sharing were mitigated. The European Directive on parent companies and subsidiaries under certain conditions exempts this income among foreign entities. Non-standard tax optimization (when companies increased the proportion of debt resources in a non-utilitarian way) was relieved by the Directive on taxation of interest and royalties among associated companies. At the national level, interest tax efficiency (eligibility) is also very often assessed by the thin capitalization test. The purpose of the measure is to reduce inappropriate use of the interest tax shield and prevent tax evasion (Karpavicius and $\mathrm{Yu}$, 2016).

Practical issues of using debt resources in the Czech Republic: The questions of capital structure formation have been designed for several decades and it is clear that the financing of business activities with the help of debt capital is attractive for companies from a wide range of reasons mentioned above. This idea reflects our research which was based on predefined factors that are important to corporate management decisions to use debt resources for its financing. These factors were investigated in the Czech Republic and companies of different sizes were addressed. The question focusing on the factors that influence the amount of debt instruments in the company was elaborated according to the weight of each factor and subsequently, depending on the size of the respondent.

The evaluation of the significance (importance) of factors affecting the company and its debt financing in the Czech Republic was investigated within the framework of the questionnaire survey. The questionnaire was processed at the Technical University of Liberec in late 2015 and 2016 and more than 200 business entities operating in the Czech Republic participated.

The question: "What factors influence the amount of debt in your company?” was answered by 185 enterprises, of which 79 were microenterprises, 48 small enterprises, 27 medium-sized enterprises and 31 large enterprises (Categorization of companies was selected based on Turnover/Balance sheet total in accordance with EC recommendation of 6 May 2003 concerning the definition of micro, small and medium-sized enterprises (2003/361/EC). Microenterprise is defined as
Table 1: Factors influencing the amount of debt in the company investigated in the \begin{tabular}{lc}
\multicolumn{1}{c}{ questionnaire survey } & Labeling \\
\hline Factors & $\mathrm{A}$ \\
Use of the interest tax shield & $\mathrm{B}$ \\
Indebtedness of other companies in the industry & $\mathrm{C}$ \\
Credit rating of the company & $\mathrm{D}$ \\
Transaction costs and fees associated with debt financing & $\mathrm{E}$ \\
The amount of personal taxes paid by the company & \\
creditors of interest (e.g. interest on bonds) & $\mathrm{F}$ \\
Financial flexibility & $\mathrm{G}$ \\
Instability in corporate profits and cash flow & $\mathrm{H}$ \\
Credibility to business partners & $\mathrm{I}$ \\
\hline Effort to maximize profits for owners
\end{tabular}

an enterprise whose annual turnover and/or annual balance sheet total does not exceed EUR 2 million. Small enterprise is an enterprise whose annual turnover and/or annual balance sheet total does not exceed EUR 10 million. Medium-sized enterprise is an enterprise which have an annual turnover not exceeding EUR 50 million, and/or an annual balance sheet total not exceeding EUR 43 million).

The companies attributed the following factors of importance on a scale of 0-4 (0-no influence, 4 -factor has a major influence) (Table 1$)$.

From the questionnaire survey results, there can be drawn the following conclusions companies, regardless of the size, view the amount of financial Flexibility (F) as the most important factor influencing decisions about a debt capital, it was evaluated on average (on a scale of 0-4) by the value of 1.77. Other important factors are an effort to maximize a profit for the owners (I) with an average importance value of 1.44 , further, instability in corporate profits and cash flow (G) with an average value of 1.33, transaction costs and fees associated with debt financing (D) with an average value of 1.32 and credibility to business partners $(\mathrm{H})$ with an average value of 1.25.

Microenterprises regard the amount of Financial flexibility (F) as the most important factor influencing decisions about debt capital-more than $20 \%$ of them consider it to be the factor with a crucial influence (on the scale indicated by value 4). Furthermore, credibility to business partners $(\mathrm{H})-15 \%$ of microenterprises consider this factor to be of a fundamental influence (on the scale indicated by value 4). Also, microenterprises assess efforts to maximize profits for the owners (I) as very important. Further, it is clear from the spider analysis (Fig. 1) that microenterprises attribute these factors greater significance than on average all companies together.

Small enterprises also regard financial Flexibility (F) as the most important factor influencing decisions about debt capital and its amount; $15 \%$ of them marked it as the factor of a major influence (on the scale indicated by value 4). Other important factors are then instability of corporate profits and cash flow (G) and credibility to business partners $(\mathrm{H})$. It is also clear from the spider 


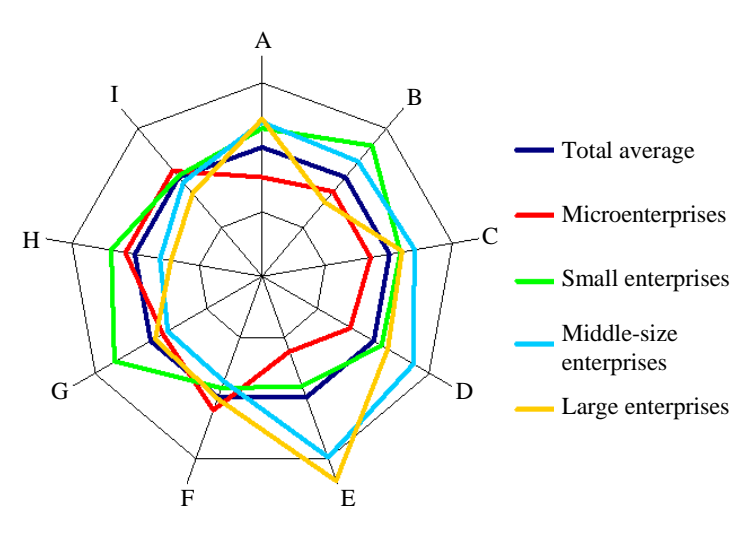

Fig. 1: The evaluation of the significance of individual criteria depending on the company size with a view to an average evaluation

analysis that the view of small enterprises varies most from the average on the importance of instability of corporate profits and cash flow and the indebtedness of other companies in the industry (B) which attribute it greater importance than it is usual.

Medium-sized enterprises regard transaction costs and fees associated with debt financing (D) as the most important factor influencing decisions about debt capital and its amount; this factor was assigned the value of 3 and 4 by one-third of medium-sized enterprises. Financial Flexibility (F) and the credit rating of the Company (C) are also regarded as an important factor. In doing so, credit rating and transaction costs and fees associated with debt financing are attributed more weight than the average which confirms the irreplaceable importance of bank loans among debt financing resources for medium-sized enterprises. Further, the medium-sized enterprises differ significantly from the average by the view on the importance of personal amount of taxes paid by the creditors of interest (E). This factor is evaluated by the medium-sized enterprises as more important than the average.

When deciding on debt capital, large enterprises like SMEs attribute the greatest importance to financial Flexibility (F), transaction costs and fees associated with debt financing (D) and the credit rating of the Company (C). Here, similar to medium-sized enterprises, the irreplaceable importance of credit financing is evident. In addition, the view of large enterprises on the importance of the amount of personal taxes paid by the company creditors of interest (E) significantly differs from the average. This factor is attributed more importance than by other enterprises which suggests that medium-sized and large enterprises use issue of bonds as a source of debt capital.
Based on the questionnaire survey, it was confirmed that the size of the company largely affects business decisions on the involvement of debt capital. While smaller enterprises in debt emphasize their credibility to business partners where higher involvement of the debt could be perceived negatively, larger enterprises focus on the credit rating, the costs associated with the debt and the taxation of interest paid to creditors. These are factors that indicate the involvement of credit and bond financing to a greater extent at medium-sized and large enterprises.

Use of debt resources in the context of Czech tax legislation: From the above findings, it is clear that companies in the Czech Republic prefer debt financing for a number of reasons. Factor A (interest tax shield) was represented in each particular group of companies, however, it was considered not significant. One of the reasons can be the current tax legislation. According to the relevant provisions of the income tax act, credits and loans from the, so-called related parties (for example from company shareholders) are problematic, since, they are subject to thin capitalization test. In situation when it is calculated that the volume of these debts exceed four times the equity, the interest corresponding to this overlap are not tax-deductible. Thus, the effect of the interest tax shield is greatly weakened and companies need to be cautious when planning debt resources. Tax legislation indirectly affects the structure of the venture capital resources-with higher equity capital increases the possibility of increased debt financing or in other words the possibility of using tax shield (Vachal and Vochozka, 2013).

In terms of the amount of personal taxes paid by the company creditors of interest (for example interest received from bonds), the tax legislation of the Czech Republic is relatively favorable due to low tax rates. If such interests are paid to individuals, they are taxed by a withholding tax in the amount of $15 \%$, interest payment for legal entities is taxed as income of the creditor at a rate of $19 \%$. This fact is also reflected in the emphasis of this factor (E) for medium-sized and large enterprises.

\section{RESULTS AND DISCUSSION}

The theoretical research suggests that unambiguous solution to the issue of construction of the capital structure of enterprises does not exist. Many factors are influenced by the decision-making process towards company's equity or debt resources. In the Czech Republic, we focused on identifying factors that companies consider important when deciding to use debt resources. It is clear from the conducted survey that a bank loan was and still is a traditional source of debt capital in the Czech Republic, especially at medium-sized and large enterprises. The significance of bond financing 
has been increasing in recent years. This is largely due to the relatively short existence of modern capital market which was restored in the 1990s as in other transition economies of Central and Eastern Europe (Serrasqueiro et al., 2014, 2016; Kumar and Rao, 2015).

There are several causes of the growing interest in the bond issue. It is particularly due to the increased regulation of banks which generally leads to lowering the importance of banks in financing the corporate sector. Furthermore, the banks are more careful when providing credits to a private sector, especially to small enterprises. The change in the attitude of investors caused by a global crisis also contributed to the higher interest of enterprises in financing via. the bond market. Low interest rates of central banks declining government bond yields caused a shift of some conservative investors from government bonds towards corporate bonds.

\section{CONCLUSION}

The development of an optimal capital structure is a very complicated task that must be satisfactorily resolved by every company. The decision to finance business activities with the help of an equity or debt capital is influenced by many factors, one of which comes to the front and that is the cost of capital. Partial income tax provisions which may limit the use of a particular kind of capital and thus significantly influence the actual cost of capital, must be also taken into account. In our research, we primarily focused on debt capital and the reasons why various large companies choose this form of financing.

The questionnaire survey showed that the company size affects the decisions regarding the involvement of debt capital. While smaller enterprises emphasize their credibility to business partners when higher participation of the debt could be perceived negatively, larger enterprises focus on credit rating, the costs associated with the debt and also on the taxation of interest paid to creditors. It can be inferred from the results that mediumsized and large enterprises are more significantly involved in credit and bond financing. Regardless of the size, the companies consider financial flexibility to be the most important factor influencing decisions about debt capital and its amount.

There is currently no clear guidance as to creating an optimal capital structure for a particular company. Still, managers must pay close attention to this task because poorly selected or unbalanced structure of funding resources could have a fatal impact on the performance of every company.

\section{ACKNOWLEDGEMENT}

This study was written as one of the outputs of the institutional support that was implemented at the Faculty of Economics of the Technical University of Liberec in 2016.

\section{REFRENCES}

Barclay, M.J. and C.W. Smith, 2005. The capital structure puzzle: The evidence revisited. J. Appl. Corporate Finance, 17: 8-17.

Doukas, J.A., J.M. Guo and B. Zhou, 2011. Hot debt markets and capital structure. Eur. Financial Manage., 17: 46-99.

Durand, D., 1952. Costs of Debt and Equity Funds for Business: Trends and Problems of Measurement. In: Conference on Research in Business Finance, Durand, D. (Ed.). NBER, New York, USA., pp: 215-262.

Eun, C.S. and L. Wang, 2015. International sourcing and capital structure. Rev. Finance, 20: 535-574.

Flannery, M.J. and K.P. Rangan, 2006. Partial adjustment toward target capital structures. J. Financial Econ., 79: 469-506.

Heins, A.J. and C.M. Sprenkle, 1969. A comment on the Modigliani-miller cost of capital thesis. Am. Econ. Rev., 59: 590-592.

Ho, W.H. and Y. Wang, 2015. Capital income taxation revisited: The roles of information friction and external finance. Pacific Econ. Rev., 20: 225-242.

Karpavicius, S. and F. Yu, 2016. Should interest expenses be tax deductible?. Econ. Modell., 54: 100-116.

Kim, E.H., 1978. A mean-variance theory of optimal capital structure and corporate debt capacity. J. Finance, 33: 45-63.

Kumar, S. and P. Rao, 2015. A conceptual framework for identifying financing preferences of SMEs. Small Enterp. Res., 22: 99-112.

Markova, H., 2015. [Tax Laws]. Grada Publishing, Prague, Czech Republic, (In Czech).

Miller, M.H. and K. Rock, 1985. Dividend policy under asymmetric information. J. Finance, 40: 1031-1051.

Miller, M.H., 1988. The Modigliani-Miller propositions after thirty years. J. Econ. Perspect., 2: 99-120.

Modigliani, F. and M.H. Miller, 1958. The cost of capital, corporation finance and the theory of investment. Am. Econ. Rev., 48: 261-297.

Modigliani, F. and M.H. Miller, 1963. Corporate income taxes and the cost of capital: A correction. Am. Econ. Rev., 53: 433-443.

Modigliani, F. and M.H. Miller, 1969. Reply to Heins and Sprenkle. Am. Econ. Rev., 59: 592-595.

Modigliani, F., 1988. MM-Past, present, future. J. Econ. Perspect., 2: 149-158.

Reznakova, M., 2012. [Effective Finance for Business Development]. Prague, Czech Republic, (In Czech) .

Serrasqueiro, Z., P.M. Nunes and D.A.M. Rocha, 2016. Capital structure decisions: Old issues, new insights from high-tech small-and medium-sized enterprises. Eur. J. Finance, 22: 59-79.

Vachal, J. and M. Vochozka, 2013. [Corporate Governance]. Grada Publishing, Prague, Czech Republic, (In Czech). 